\title{
Distribution of Assets After Divorce of Members Indonesian Army (TNI) AD DIKODAM I/BB Perspective Legal Standing Civil Inheritance
}

\author{
Ali Mukti Tanjung ${ }^{*}$, Dahris Siregar, and Muhammad Nurrohim \\ Universitas Pembinaan Masyarakat Indonesia \\ *Corresponding author email: alimuktitanjung445@gmail.com
}

\begin{abstract}
Based on the facts that happened to Indonesian Army (TNI) members, there is a difference between the legal practice that developed in soldiers carrying out divorce at Bintaldam I/BB and how the expectations of Islamic law in Islamic legal literature, especially in terms of sharing of joint assets after divorce. The problems that occur are the problem of joint property after divorce is not divided properly. Research methods used in this research analysis of data and legal materials by analyzing legal materials obtained in literature study research, statutory regulations, and other legal materials will be described and linked in such a way, so that they are presented in a more systematic research in order to answer the problems that have been formulated to get to a conclusion. From the results of this research, it can be concluded that: The division of joint assets is often carried out by soldiers by not dividing them first because there is still a lack of knowledge regarding the distribution of joint assets in accordance with the law. The habits of the soldiers, namely when one of the husband and wife divorces, in general, they do not share the joint property in advance, and some do not even share it at all. Even though this habit has become a living thing in the midst of Soldiers, it does not rule out the possibility that later it will cause problems. This happened because of the lack of understanding with applicable law.
\end{abstract}

Keywords: Common Property, TNI (Indonesia Army), Post Divorce

\section{INTRODUCTION}

Problems in marriage arise when the goals in marriage are not achieved, rights or obligations are not fulfilled, such as being unable to have sexual relations, not producing offspring, or bad behavior from one party and so on. In these circumstances, marriage as a relationship can be terminated by one of the two married parties [1]-[3].

This termination of the marriage relationship became known as divorce, or divorce in fiqh. In fiqh, divorce is defined as the renouncing of the marriage bond or ending the husband and wife relationship [4]-[7].

Collective assets can be in the form of intangible objects (rights and obligations), movable objects, immovable objects and securities. As long as it is not regulated otherwise in the marriage agreement, in the event of a divorce, both the wife and husband are entitled to half (half) of the joint assets. In the case of joint assets, the wife often loses and experiences injustice in the distribution of joint assets. This injustice is related to the problem of standardizing the roles of husband and wife in Law No. 1 of 1974 [8] concerning marriage The Marriage Law states that the husband is the head of the family and the wife of the housewife.

Temporary investigations show that when Divorce occurred among the TNI, soldiers who were divorced were reluctant to share their assets together [9]-[10]. 
Departing from one understanding that post-divorce joint property is not shared between the divorced husband and wife, but is only controlled by one party. From the description of the legal phenomenon above, of course, it runs away from the noble purpose of law which should be used as social control social engineering that can be felt and enforced in the midst of society, especially soldiers carrying out divorce at the Military Military Command I Mental Development Unit/Bukit Barisan (Bintaldam $\mathrm{I} / \mathrm{BB})$.

This research departs from the fact that there is a difference between the legal practice that develops in soldiers who carry out divorce at Bintaldam I/BB and how the expectations of Islamic law in Islamic legal literature, especially in terms of sharing of joint assets after divorce. Therefore, the problem of post-divorce joint property that is not divided properly is the main problem in this research, namely that it is not carried out by husband and wife after carrying out a divorce, joint property is not divided according to the applicable legal provisions.

\section{METHODOLOGY}

\subsection{Research Location}

The place or location of research in writing this thesis is in the Military Military Command I/Bukit Barisan Mental Development Unit, because there is enough data and affordable to the author and easy to communicate in data collection.

\subsection{Data Collection Techniques}

As a follow-up in obtaining data as expected, it is necessary to collect data with the following techniques:

a. Interview. The interview technique in this research was used to collect primary data. The interview used is a structured interview (interview guide). Interviews were conducted using question guidelines previously prepared by the researcher. In-depth interviews were conducted (in-depth interviewing) with respondents and Bintaldam I/Bukit Barisan.

b. Document Study (file). It is a data collection method by examining and reviewing documents, literature books, laws and regulations, articles obtained through mass media and electronic media, papers, and research results relevant to the object of research.

\subsection{Data Analysis}

Analysis of data and legal materials by analyzing legal materials obtained in literature study research, statutory regulations, and other legal materials will be described and linked in such a way, so that they are presented in a more systematic research in order to answer the problems that have been formulated previously. Whereas the method of processing legal materials is carried out deductively, namely drawing conclusions from a general problem regarding the concrete events that occur.

\section{RESULT AND DISCUSSION}

\subsection{Implementation of Collective Assets Sharing After Divorce of Soldier at Bintaldam I/BB}

The distribution of joint assets by soldiers of the Military Command I/Bukit Barisan resulted in various women and opinions after the divorce. In every divorce case, the issue of collective property always enlivens the courtroom. So, it is not only the issue of the separation of the marital relationship that is brought to trial, but also the issue of the distribution of assets between husband and wife. Not only has the right in terms of the relationship status as husband or wife, but also the feeling of being entitled to the assets owned by the partner. So, it is as if, with the existence of marital status, a person's property becomes the property of his partner automatically, even without an agreement. But unfortunately, the sense of belonging is only when the husband has a lot of assets, but this does not apply when the husband is in debt. If the property becomes joint property, but the debt remains its own debt. In fact, this phenomenon, a sense of belonging and a sense of belonging to a partner's property, is common in society. But what becomes a problem then is that the sense of entitlement that arises is only limited to use and use rights or also the right to own property like one's own.

Responding to the status of use rights and ownership rights like this, each of them has consequences. If it is said that it is only limited to use rights, then each spouse may only use his partner's assets as long as their respective marital status is running, not more than that. It may use, but not sell [11]-[16].

An example of Case 1 happened to the pair Lettu Caj Ahmad Yani and Lettu Caj (K) Rama Yulis. Ahmad Yani is married to Rama Yulis. And Ahmad Yani already has a house that is certified. After they got married, Rama Yulis had the right to use Ahmad Yani's house, just like a husband's responsibility for his wife. But it is not certain that Rama Yulis has ownership rights to the house. Rama Yulis may use the house as a residence, but Rama Yulis cannot sell the house or mortgage the certificate without Ahmad Yani's permission.

Furthermore, if the house and the certificate belonged to Ahmad Yani, then when the divorce took place, Rama Yulis would no longer have rights over the house. This 
means that the house cannot be sued on the basis of collective assets.

As a rationale for the inaccurate definition of joint assets or Gono Gini assets. Joint assets (gono-gini) are property or assets obtained during the marriage. Even though the assets are obtained from the husband's work alone, the wife still has the right to joint property. Thus, joint assets include assets obtained from the business of the husband and wife together or the business of one of them. This means that both husband and wife have the same rights and obligations over joint property and all Legal actions regarding joint property must be approved by both parties. Collective assets can be in the form of tangible objects, intangible objects (rights and obligations), movable objects, immovable objects and securities.

As long as the marriage agreement is not regulated otherwise, in the event of a divorce, each wife and husband are entitled to half of the joint assets.

Meanwhile, violations of divorced husbands and wives occur due to several factors, limitations regarding legal knowledge. If you understand the meaning of Gono-gini assets in the KHI (compilation of Islamic Law) as described below, God willing, things will not happen that violate the provisions of the applicable law.

In the KHI, the book Marriage chapter XIII "PROPERTY OF PROPERTY IN MARRIAGE" states as follows.

Art 86

1. Basically there is no mixing between the husband's assets and the wife's assets because of marriage.

2. Wife's property remains the wife's right and is fully controlled by her, likewise the husband's property remains the right of the husband and is fully controlled by him.

Art 87

1. The inheritance of each husband and wife and the property that is obtained by each as a wasiah or inheritance is under their respective control, as long as the parties do not specify otherwise in the marriage agreement.

2. Husband and wife have the full right to take legal actions on their respective assets in the form of a gift, gift, sodaqah or other.

Explanation of the Judges in I/Bukit Barisan regarding the Sharing of Assets with Soldiers of the Military Command I/Bukit Barisan after the divorce

Included as joint assets (Gono-gini) according to Drs. Suherman, M.Si, to find out the status of assets, whether they are considered as legal or not, it can be seen from the agreement that happened. Basically, what it is meant by joint property (gono-gini) is property that is obtained simultaneously, not solely on the existence of marital status. This needs to be understood.

Zakaria Anshori further explained the Gono Gini Treasure in Islam. In fact, Islam does not recognize the term treasure gono-gini as it is understood by the majority of society. That is an understanding that makes marital status proof of the partner's property ownership. Because what the wife has right to property is only limited to the adequacy of the livelihood (welfare) provided by the husband according to his ability, not the husband's total assets.

When a divorce occurs, the rights of each spouse are:

1. Each partner has the right to bring and acknowledge his personal assets, whatever the form.

2. Each spouse is entitled to joint property (gono-gini). That is, property that is clearly joint property, not each partner's or one partners. In this case, the husband's assets cannot be considered as gono-gini assets. This is regulated in the Marriage Law.

An even more sadistic thing was that there was a case that did not share shared assets after the divorce, namely that one of the soldiers with the rank of Captain who was divorced in 2011 did not share assets after the divorce. Then in the same case from another unit with the rank of Serma, M. Ridwan Saragih. Namely those who divorced on 27 October 2014 also did not share their joint assets after the divorce.

Table 1 Results of interviews regarding the distribution of assets jointly by families and soldiers

\begin{tabular}{lcc}
\hline \multicolumn{1}{c}{ Answer } & Number of interviews & Proportion $(\%)$ \\
\hline Divide & 0 & 0 \\
Not dividing & 12 & 97.3 \\
No answer & 3 & 2.7 \\
\hline Total & 15 & 100 \\
\hline
\end{tabular}

Respondents who did not answer about the distribution of joint assets when there was a divorce because of the background of death because they kept their family problems secret, this was considered a sensitive issue and did not want people to know.

From this data, it can be seen that the majority of the people of the Tamalanrea sub-district (97.2) do not share in advance the joint assets arising from divorce.

The law is enforced for the sake of legal certainty. The juridical positivism of sharing assets together in (Law No. 1 of 1974 [8]) is regulated in Articles 35-37, Compilation of Islamic law, Articles 85-97, Article 128 BW. The instrument of the laws and regulations actually illustrates that the sharing of joint assets is something important to ensure legal certainty for the parties, so that no one is harmed. The habit of society when death occurs, whether 
it is the husband or wife, does not share it immediately, even though the habit has become a living thing in society, it does not rule out the possibility that it will cause problems in the future.

The distribution of wealth in a marriage is always an important part of a divorce, be it divorce or divorce. This can be seen from the number of cases that have attracted public attention to the distribution of joint assets. As the classic Malay proverb states, "it is thought that it is hot until evening, it will rain in the middle of the day".

The point of this classic advice is that everything can and may happen in human life. The common practice of not sharing shared assets during a divorce due to death is a bad precedent. Sharing of joint assets due to divorce is important so that the total amount of assets of the husband or wife who died can be clearly determined. The purpose of this separation of assets is so that the party who is left behind, namely husband or wife and heirs, can take care of the completeness of the law in managing the rights and obligations of the deceased and guaranteeing justice for the parties.

Based on the results of interviews with Kasi Rohis Bintaldam I/Bukit Barisan Mayor Caj Drs. Zakaria Anshori, M.H, that the habits carried out by the community by not sharing shared assets after a death in a legal juridical context are things that are contrary to statutory regulations. The habits of the common people are counterproductive with the aim of developing and increasing awareness of legal understanding in society.

The main purpose of sharing the assets together is actually the fulfillment of a sense of justice. Likewise, all court decisions must reflect this dimension of justice. The religious court itself rarely accepts cases of sharing of joint assets from divorce. Cases of joint assets from dead divorce that enter generally have become inheritance cases and the amount is quite a lot. If the public has fully understood the importance of sharing the assets together, of course in the future there will be no problems like this. The same thing was conveyed by Letkol Caj Drs. Suherman, a judge at Bintaldam I/Bukit Barisan that the main problem actually lies in legal awareness and a lack of understanding of the importance of sharing joint assets first after a divorce occurs, this is important because there are rights and obligations arising from these joint assets. The joint property is indeed a commitment of legal unification efforts to resolve conflicts that may arise between parties due to legal pluralism. There is a need for scheduled and planned legal counseling so that the general public can understand their rights and obligations.

Results of Interviews by the Bintaldam Judges addressing Soldiers' understanding of the Law in Sharing Collective Assets Post Divorce
From a number of audiences, they answered that they understood a number of 0 (nil) answered doubtfully a number of $80 \%$ and answered did not know a number of $10 \%$ and did not answer $10 \%$. This shows that the need for steps from the parties concerned to provide legal knowledge to soldiers and their families.

Table 2 The results of the interview regarding the soldiers' understanding of the distribution of assets after the

divorce

\begin{tabular}{lcc}
\hline \multicolumn{1}{c}{ Answer } & $\begin{array}{c}\text { Number of } \\
\text { interviews }\end{array}$ & $\begin{array}{c}\text { Proportion } \\
(\%)\end{array}$ \\
\hline Understood & 0 & 0 \\
Doubt & 11 & 80 \\
Did not understand & 2 & 10 \\
Did not answer & 2 & 10 \\
\hline Total & 15 & 100 \\
\hline
\end{tabular}

\subsection{Things that are Background of Collective} Prices Not Division by the Laws Applicable Post Divorce of Personnel at Kodam I Bukit Barisan

From the table above, it can be seen that there are still many Soldiers who do not know about joint property. In general, they think that there is no separation between shared assets and assets, so they confuse the two things, namely shared assets and assets. The concept of joint property dissolves in the event of a divorce, but this concept is not implemented by most people, this is due to the lack of understanding of the community about joint assets, thus giving birth to a problem that occurs within soldiers, namely regarding the sharing of joint assets, especially after divorce.

Soldiers generally think that when there is a divorce, neither the husband nor the wife share it right away, even though in the provisions of the marriage law this is something important so that the total amount of the assets of the husband or wife who dies can be clearly determined. From a philosophical aspect, the benefits of this separation of shared assets are that the parties, namely the wife or husband and the heirs, can be guaranteed the fulfillment of justice for those who are entitled to receive. Soldiers' lack of understanding of the conception of the sharing of shared assets had a major impact on Soldiers and society. Between law and other social norms, there is a close intertwined relationship, one which strengthens the other. Sometimes the law is not in accordance with or in harmony with other social norms. Teaching order finding disorder, studying regularity (law) will find an irregularity. Maybe this is the right term to describe that the law in this country is indeed chaotic. In the context of legal certainty, of course the habits that live in the 
community are seen as something that is opposite or not in line with the laws and regulations. however, when viewed from the perspective of legal habits or customs living in society, of course this also needs special attention.

According to Soerjono Soekanto, the community's habits cannot be separated from legal awareness. According to Soerjono Soekanto, indicators of legal awareness are actually relatively concrete indicators of the level of legal awareness. It was explained again briefly that the indicators affecting the legal awareness of Soldiers in the sharing of joint assets were caused by:

1. Legal knowledge. A person knows that certain behaviors are regulated by law. Legal regulations referred to here are written and unwritten laws. This behavior concerns behavior that is prohibited by law or behavior that is permitted by law.

2. Understanding of the law. A Soldier has knowledge and understanding of certain rules, for example the existence of correct knowledge and understanding from Soldiers about the nature and importance of Law No. 1 of 1974 [8] concerning marriage.

3. Legal attitude. A person has a tendency to make certain judgments about the law

4. Legal behavior, namely where a person or in a soldier obeys the applicable rules.

The four indicators above simultaneously show the levels in certain legal awareness in its realization. If someone knows the law. it can be said that the level of legal awareness is still low, but if someone or a society has behaved according to the law, then the level of legal awareness is high.

Compliance is an active attitude based on motivation after he has acquired knowledge. From knowing something, humans are aware, after realizing they will be moved to determine an attitude or act. Therefore, the basis for compliance is education, habits, benefit and group identification. So, because of education, accustomed, aware of its benefits and to identify himself in the human group will obey.

Another factor that affects the habit of the Soldier is the legal culture that lives in society. In the culture of Muslim society, in relation to the assets obtained in a marriage, there are two cultures that apply, first: the culture of society which separates the assets of the husband and the assets of the wife in a household. In Muslim societies like this, there is no term shared assets. Second: Muslim soldiers who do not separate the assets obtained by husband and wife in marriage. Muslim warriors like this recognize and acknowledge common property. Muslim soldiers who acknowledge the existence of shared assets have become stronger, because it is stated in Article 35 paragraph (1) of the Marriage Law.

The legal culture that lives in this society has more or less influenced the habits carried out by the community regarding the distribution of the collective property. Soldiers who do not share in advance the joint assets of divorce because the death is usually influenced by the legal culture that recognizes the existence of joint assets.

The habit of soldiers who do not share property together with the breakup of a marriage due to death basically applies the law in the aspect of utility the practical value of the habit is felt to be easier than bothering to share it in advance. This habit of course overrides the aspect of legal certainty and the aspect of legal justice itself.

\section{CONCLUSION}

1. The division of joint assets is often carried out by soldiers by not dividing it first because there is still a lack of knowledge regarding the distribution of joint assets according to law. The soldiers still maintained the prevailing habits

2. The habits of the soldiers, namely when one of the husband and wife divorces, in general, they do not share the joint assets in advance. Even though this habit has become a living thing in the midst of Soldiers, it does not rule out the possibility that later it will cause problems. This happened because of the lack of understanding with the applicable law.

\section{REFERENCES}

[1] R. G. Henry, R. B. Miller, Marital Problems Occurring in Midlife: Implications for Couples Therapists. American Journal of Family Therapy, 32 (5) (2004), 405-417.

[2] K. S. Birditt, E. Brown, T. L. Orbuch, J. M. McIlvane, Marital Conflict Behaviors and Implications for Divorce over 16 Years. J Marriage Fam., 72 (5) (2010), 1188-1204.

[3] J. P. Dew, R. Stewart, A Financial Issue, a Relationship Issue, or Both? Examining the Predictors of Marital Financial Conflict. The Journal of Financial Therapy, 3 (1) (2012), 43-61.

[4] A. Manan, Problematika Perceraian karena zina dalam proses penyelesaian perkara di lingkungan peradilan agama. Jurnal Mimbar Hukum, Al-Hikmah \& DITBINBAPERA, 52 (2001). 
[5] L. M. Bani, H. A. Pate, Dissolution of Marriage (Divorce) under Islamic Law. Journal of Law, Policy and Globalization, 42 (2015), 138-143.

[6] I. Hidayat, Yaswirman, Mardenis, Problems Arising from Talak Divorce Outside the Court. International Journal of Multicultural and Multireligious Understanding, 6 (4) (2019), 138-148.

[7] A. Bone, Islamic Marriage and Divorce in the United Kingdom: The Case for a New Paradigm. Journal of Muslim Minority Affairs, 40 (1) (2020), 163178 .

[8] Undang-Undang No. 1 Tahun 1974 tentang Perkawinan.

[9] L. Wang, A. Seelig, S. M. Wadsworth, H. McMaster, J. E. Alcaraz, N. F. Crum-Cianflone, Associations of military divorce with mental, behavioral, and physical health outcomes. BMC Psychiatry, 15 (128) (2015), 12 pages.

[10] C. M. Pethrus, J. Reutfors, K. Johansson, K. Neovius, J. Söderling, Marriage and divorce after military deployment to Afghanistan: A matched cohort study from Sweden. PLOS ONE, 14 (2) (2019), e0207981.

[11] E. Rochaeti, Analisis Yuridis tentang Harta Bersama (Gono Gini) dalam Perkawinan Menurut Pandangan Hukum Islam dan Hukum Positif. Jurnal Wawasan Hukum, 28 (1) (2013), 650-661.

[12] S. Hariati, M. Salat, Ketidakadilan Pembagian Harta Gono Gini pada Kasus Perceraian - The Injustice of Distributing Marital Property (Harta Gini Gono) in Divorce Cases. Kajian Hukum dan Keadilan, 448-463.

[13] B. Sugiswati, Konsepsi Harta Bersama dari Perspektif Hukum Islam, Kitab Undang-Undang Hukum Perdata dan Hukum Adat. Perspektif, 19 (3) (2014), 201-211.

[14] M. T. Pradoto, Aspek Yuridis Pembagian Harta Bersama dalam Perkawinan (Tinjauan Hukum Islam dan Hukum Perdata). Jurisprudence, 4 (2) (2014), 8591.

[15] B. Nagara, Pembagian Harta Gono-Gini atau Harta Bersama setelah Perceraian menurut Undang-Undang Nomor 1 Tahun 1974. Lex Crimen, 5 (7) (2016), 51-57.

[16] M. B. Kurniawan, Pembagian Harta Bersama Ditinjau dari Besaran Kontribusi Suami Istri dalam Perkawinan - Equitable Distribution of Matrimonial Property based on the Contribution of Each Spouse. Jurnal Yudisial, 11 (1) (2018), 41-53. 